\title{
PURSUING THE INTRINSIC RELATIONSHIP BETWEEN LITURGY AND ETHICS: PRACTICAL- THEOLOGICAL PROMISE IN POVERTY OF SPIRIT
}

BRUCE T.MORRILL S J

ABSTRACT

This article examines whether and how sacramental liturgy and the Christian life-ethic are intrinsically related, a fundamental problematic in theory and practice in the decades since Vatican Council II. The first half of the essay examines the state of the question, starting with a brief articulation of the normative tradition based in scripture and the council's Constitution on the Sacred Liturgy, followed by a selective review of the theological discussion, centered on Don E. Saliers's virtue-ethics approach. The second half, building on a thesis of Johann Baptist Metz, argues for poverty of spirit as the key virtue for practically bonding liturgy and ethics.

Key words:

Liturgy; Ethics; Virtues; Poverty; J. B. Metz; Don Saliers

DOI: $10.14712 / 23363398.2020 .45$

To

o think about the relationship between liturgy and ethics is to think of the latter not as a deductive system of principles for personal and social behavior but, rather, in broader terms of the images, personages, myths and narratives, symbols and rituals, affections and virtues, as well as principles, by which people shape their views of the world and how to live justly within it. ${ }^{1}$ In my judgment (although, as will soon become evident, not original to me), such a character-and-virtue

1 See David N. Power and Michael Downey, Living the Justice of the Triune God (Collegeville: Liturgical Press, 2012), 128-30. In his treatment of the topic, liturgical theologian Don Saliers means by ethics, 'the concrete [Christian] way of life rather than theoretical interpretations of ethical theory ... a way of life before God in relation to our neighbor' Don E. Saliers, Worship as Theology: Foretaste of Glory Divine (Nashville: Abingdon Press, 1994), 172-173. 
approach to ethics ${ }^{2}$ makes fundamental to the problematic of liturgy and ethics the question as to whether and how there is an intrinsic relationship between the two. That theoretical, conceptual question comprises the first half of this essay, beginning with a brief explication, grounded in the doctrine of Vatican Council II, of the normative nature of claiming an intrinsic relationship between liturgy and ethics in scripture and tradition. Then will follow a review of the contemporary conceptualization of the normative, intrinsic bond between liturgy and ethics, anchored in the decades-long, widely-read work of liturgical theologian Don E. Saliers. Inquiry into the normative, conceptual relationship between liturgy and ethics, given the performative nature of both those theological loci, inevitably points toward challenges to and complementary resources for the affective practice of faith through biblically-grounded virtues. The second half of the essay, then, shall explore the potential of one such virtue, poverty of spirit, for theoretically reinforcing and practically enhancing participation in liturgy as formative of a Christian life-ethic.

\section{A Brief, Contemporary Overview of Scripture and Tradition}

For well more than a half-century now the Second Vatican Council's Constitution on the Sacred Liturgy, Sacrosanctum concilium (1963), has been the authoritative traditional source for the theology and practice of the sacraments and other rites of the Catholic Church. Having built upon not only specific liturgical reforms of earlier twentieth-century papacies but also, importantly, a century-long and increasingly ecumenical Liturgical Movement, ${ }^{3}$ the constitution quickly came to function as the charter document for sacramental-liturgical renewal in numerous Anglican and Protestant communions, as well. In its inaugural position among the major documents of Vatican Council II, the constitution so integrated the life of the liturgy and the life of the

See Philippe Bordeyne, 'The Ethical Horizon of Liturgy,' in Sacraments: Revelation of the Humanity of God, ed. Philippe Bordeyne and Bruce T. Morrill (Collegeville: Liturgical Press, 2008), 121-124. French language version, 'L'horizon éthique de la liturgie,' in Les sacrements révélation de l'humanité de Dieu: Volume offert à Louis-Marie Chauvet (Paris: Les Éditions du Cerf, 2008), 166-170.

3 See André Haquin, 'The Liturgical Movement and Catholic Ritual Revision,' and Geoffrey Wainwright, 'Ecumenical Convergences,' in The Oxford History of Christian Worship, ed. Geoffrey Wainwright and Karen B. Westerfield Tucker (Oxford: Oxford University Press, 2006), 696-754. 
church as to foster an ecclesiological vision that would reach through all the ensuing documents, especially the two constitutions on the church: first, the dogmatic one, articulating the normative tradition, and second, the pastoral one, addressing the promise and challenges for not only the church but all humanity in the practical conditions of the late-modern world. ${ }^{4}$

In the renewal of the church going forward, Sacrosanctum concilium establishes liturgy as having an integral function, indicated by the subtitle of the opening section of the first chapter, 'The Nature of the Sacred Liturgy and Its Importance in the Church's Life'. Therein the constitution describes the church's work of forming and reforming believers as follows: '... the Church must ever preach faith and penance, prepare them for the sacraments, teach them to observe all that Christ has commanded, and invite them to all the works of charity, worship, and the apostolate. For all these works make it clear that Christ's faithful, though not of this world, are to be the light of the world and to glorify the Father in the eyes of all'.5 The allusion to the Last Discourse in John's Gospel articulates the challenge believers perennially experience in striving to make the gospel the primary source of their worldview, or 'lifeworld, ${ }^{9}$ in tension with or even at times opposition to the predominant 'social imaginary'7 of their given place and time. The council fathers couple that Johannine symbol of being in but not of the world ${ }^{8}$ to Christ's ethical exhortation to his hearers in Matthew's Sermon on the Mount who, being 'the light of the world,' are to practice such 'good deeds' as to lead others to acknowledge God. In that acknowledgement is God glorified. ${ }^{9}$ The Constitution immediately goes on to assert:

4 For a recent account, with multiple bibliographical references to earlier works on the topic, see Stephen Bullivant, Mass Exodus: Catholic Disaffiliation in Britain and America Since Vatican II (Oxford: Oxford University Press, 2019), 142.

5 Constitution on the Sacred Liturgy: Sacrosanctum Concilium, no. 9, trans. International Commission on English in the Liturgy, in The Liturgy Documents: A Parish Resource: Volume One, 4th ed. (Chicago: Liturgy Training Publications, 2004), 5.

6 For an explanation and application of the concept of 'lifeworld,' whereby Jürgen Habermas theorizes the importance of 'the immediate milieu,' of 'intersubjective communication and action' through which 'the individual social actor' engages social, political, and cultural systems, see Power and Downey, 10-12.

7 For discussion of this concept, see further below.

8 See John 15:19; 17:16.

9 Matt 5:14-16. English biblical quotations are taken from The New Revised Standard Version. 
Still, the liturgy is the summit toward which the activity of the Church is directed; at the same time, it is the fount from which all the Church's power flows. ... From the liturgy, therefore, particularly the Eucharist, grace is poured forth upon us as from a fountain; the liturgy is the source for achieving in the most effective way possible human sanctification and God's glorification, the end to which all the Church's other activities are directed. ${ }^{10}$

That same paragraph speaks of the Eucharist as providing the ongoing 'renewal' of the covenant between God and the faithful, so as to be 'compelled' by Christ's love, which 'sets them on fire'. Believers need to be compelled, need constantly to be renewed, promoted and empowered for their mission in but not of the world.

And yet, the New Testament gives evidence of how even the liturgical assembling on the Lord's Day can fail to accomplish its eucharistic purpose. Paul bluntly asserts to the wealthier Corinthians, who drink and dine in disdainful disregard for the poor, late-arriving laborers of the community, that their ethical failure is likewise a mystical (sacramental) one: 'When you come together it is not really to eat the Lord's supper..$^{11}$ Likewise, the Johannine tradition that professes Jesus as the bread of life and recounts him during the Last Supper commanding his disciples to mutual love and service, finds itself obliged in a subsequent epistle to admonish: "Those who say, "I love God", and hate their brothers or sisters are liars; for those who do not love a brother or sister whom they have seen, cannot love God whom they have not seen.. ${ }^{12}$ What becomes evident in primordial Christian tradition is that human sanctification is anything but a matter simply between the individual and God; rather, God's glorification comes through a way of life, liturgical and ethical, that is irreducibly communal, interpersonal and social.

What the Johannine and Pauline traditions, among others in the New Testament canon, present may be summarized as asserting that the entire Christian life is the worship of God. The way believers live

\footnotetext{
Constitution on the Sacred Liturgy, no. 10.

111 Cor 11:20. For a still important, leading essay in English-language biblical scholarship, see Jerome Murphy-O'Connor, 'Eucharist and Community in First Corinthians,' Worship 51, no. 1 (January 1977): 56-69. See also, Xavier Léon-Dufour, Sharing the Eucharistic Bread: The Witness of the New Testament, trans. Matthew J. O'Connell (New York: Paulist Press, 1987), 203-229.

121 John 4:20. See also, John 6:35; 13:14-15, 34-35.
} 
in their bodies, Paul teaches, makes them 'a living sacrifice,' practicing a holiness that constitutes their 'spiritual worship,' or as the First Letter of Peter puts it, 'living stones' who are being 'built into a spiritual house.. ${ }^{13}$ Jean-Marie-Roger Tillard comments on 1 Peter: 'The whole letter is permeated by the conviction that this holiness - the form taken by life led in the "priestly community" - finds its material first of all in a specific relationship with others, even non-Christians. ${ }^{14}$ Tillard marshals numerous other New Testament passages, along with patristic letters and homilies engaging them, to show how worship or sacrifice or offering (leitourgia) is 'no longer just a question of ritual liturgy. It is a question of life as such, empowered by the process of its being laid down. ${ }^{15}$

Sacramental liturgy is the means whereby Christians, not least in the very assembling as Christ's body, are empowered by (biblical) word and symbols making explicit for them the mystery of salvation God's Spirit is working out so often in hidden or scattered ways across their lives and in wider society. ${ }^{16}$ The people of God must continuously come together on the Lord's Day to gather and share the fragmented stories of their lives as a participation in the human story of God. ${ }^{17}$ Hence the Constitution on the Sacred Liturgy's rhetoric for the liturgy, especially the Eucharist, as the source (or fountain) and summit of the church's mission in its members. The time of the church is an ongoing advent wherein believers proclaim the death of the Lord until he comes, ${ }^{18}$ actively await a new heaven and a new earth, ${ }^{19}$ variably realizing and falling short of that proclamation and promise in their lives, personally, ecclesially, and societally.

13 Rom 12:1; 1 Pet 2:5.

14 J.-M.-R. Tillard, Flesh of the Church, Flesh of Christ: at the Source of the Ecclesiology of Communion, trans. Madeleine Beaumont (Collegeville: Liturgical Press, 2001), 23.

15 Ibid., 97. See also, 105-107.

16 See Bruce T. Morrill, Divine Worship and Human Healing: Liturgical Theology at the Margins of Life and Death (Collegeville: Liturgical Press, 2009), 5-9; and 'Liturgy, Ethics, and Politics: Constructive Inquiry into the Traditional Notion of Participation in Mystery,' in Mediating Mysteries, Understanding Liturgies: On Bridging the Gap Between Liturgy and Systematic Theology, ed. Joris Geldhof. Bibliotheca Ephemeridum Theologicarum Lovaniensium 278 (Leuven: Peeters Publishing, 2015), 187-206. Here I borrow from the theory and symbolic terminology of Edward Schillebeeckx, as shall be discussed and documented further below.

18 See 1 Cor 11:26.

19 See 2 Pet 3:13; Rev 21:1. 


\section{The Conceptual Problematic: Thinking with Don E. Saliers}

Within a decade after Vatican Council II, the relationship between liturgy and ethics became a topic of investigation for a certain number of sacramental-liturgical theologians and, to a lesser extent, theological ethicists. Among the more notable theorists of the question to emerge in that period was the Methodist theologian of liturgy and spirituality Don E. Saliers. Writing in the latter 1970s, ${ }^{20}$ Saliers found the topic in need of conceptual clarity, not only in light of societal changes that had significantly impacted the perception and even viability of formal church worship but also due to what he observed, with dismay, to be theological and pastoral-liturgical strategies focused on personal feelings and social themes-of-the-moment. Saliers's essay proved programmatic for addressing anew the problem and then pressing a normative claim, resonant with Sacrosanctum concilium and influenced by his Wesleyan heritage, founded upon ancient tradition's joining of the glorification of God with the sanctification of people.

Saliers' theological vision, which he advanced and critically revisited in the $1990 \mathrm{~s},{ }^{21}$ is a holistic one for Christian life in community, an ongoing process of liturgically forming and reforming affections and virtues that dispose the faithful to assess and act ethically in concrete life-contexts and situations.

How we pray and worship is linked to how we live - to our desires, emotions, attitudes, beliefs and actions. This is the normative claim of all communities intending to be faithful to Scripture and the inner norms of the Church's declaration of faith. Yet how we pray and worship is, empirically considered, often radically in conflict with how we live. Such is the description of what is the case sociologically. Upon this gap between the 'rhetoric' and the 'reality' of liturgical worship we have recently had no end

20 See Don E. Saliers, 'Liturgy and Ethics: Some New Beginnings,' Journal of Religious Ethics 7, no. 2 (Fall 1979): 173-189. Reprinted in Introduction to Christian Ethics: A Reader, ed. Ronald P. Hamel and Kenneth R. Himes (Mahwah, NJ: Paulist Press, 1989), 175-184; and in Liturgy and the Moral Self: Humanity at Full Stretch Before God, ed. E. Byron Anderson and Bruce T. Morrill (Collegeville, MN: Liturgical Press, 1998), 15-35.

21 See 'For the Sake of the World: Liturgy and Ethics,' in Saliers, Worship as Theology, 171-190; and Don E. Saliers, 'Afterword: Liturgy and Ethics Revisited,' in Liturgy and the Moral Self, 209-224. 
of commentary. ... The fundamental conviction undergirding [this essay] is that, properly considered, there is an internal, conceptual link between liturgy and ethics. At the foundations of Christian faith and throughout Jewish teachings, liturgy and ethics are bound together internally. That is, the link is not causal and extrinsic, but conceptual and intrinsic. Our problem is how to articulate this without doing injustice to the complexity of other relationships between liturgy and ethics which can be described. ${ }^{22}$

Saliers's insistence on the 'conceptual and intrinsic' relationship between liturgy and ethics 'as a concrete way of life before God with neighbor ${ }^{23}$ is not unlike Catholic moral theologian Pierre Bordeyne, building on the work of the late William Spohn, ${ }^{24}$ enlisting the parable of the Good Samaritan: Luke frames the parable with the dialogue between Jesus and the lawyer concerning the twofold commandant of love for God and neighbor and Christ's concluding command, 'Go and do likewise' (Luke 10:37), thereby prompting reflection on who the believer might become in following this Jesus. ${ }^{25}$ Formation of character in the virtues thereby constitutes the practical basis for ethics in Christian life, the empowerment of which, analogously to Luke's narrative, comes through a 'transforming encounter with the risen Christ,' subjectively experienced in prayerful word and sacrament, especially the Eucharist. ${ }^{26}$

What Saliers means by insisting on the relationship between liturgy and ethics as conceptual and intrinsic may further be understood by considering what he is arguing against. Saliers opposes efforts in theory and practice to forge an 'extrinsic and causal' link between the two, about which he comments: 'This approach is reinforced by the easy assumptions of sociology and psychology of religion in our time. ${ }^{27}$ Saliers was writing at the end of an era, a decade after the social and cultural upheavals initiated in the latter 1960s, wherein relevance and

22 Saliers, 'Liturgy and Ethics,' 174.

23 Ibid.

24 See William C. Spohn, God and Do Likewise: Jesus and Ethics (New York: Continuum, 2000).

25 Bordeyne, 'The Ethical Horizon of Liturgy,' 125. French language version, 171-172. For a discussion of parable as the narrative type that brings to the fore the ethical consequences and implications of the biblical 'great story' (of creation, covenants, and Christ), see Power and Downey, Living the Justice of the Triune God, 62-63.

26 Bordeyne, 'The Ethical Horizon of Liturgy,' 125 (emphasis original); French language version, 171-172.

27 Saliers, 'Liturgy and Ethics,' 174. 
practicality (action and results) in the urgency for social change put into question the utility of doing liturgy or other traditional religious practices.

While not referencing him in that 1979 essay, Saliers greatly admired and drew from the work of the Orthodox liturgical theologian Alexander Schmemann, ${ }^{28}$ who in books and essays produced from the 1960 s to early 1980s regularly denounced efforts, both academic and pastoral, to make liturgy more 'relevant' and useful for people's lives. Schmemann bemoaned what he characterized as turning liturgy into a means of 'help' with people's psychological and personal growth, while he excoriated new, experimental liturgies thematically addressing social-political issues and conflicts of the day. ${ }^{29}$ This, to employ Saliers's language, is to distort liturgy into 'an instrument to get things done, ${ }^{30}$ stripping it of its very nature - as praise and thanksgiving, anamnesis and epiclesis, invocation and beseeching, intercession and lament - and thereby of the divine grace it offers humanity: 'Liturgy is the nonutilitarian enactment of the drama of the divine-human encounter, made flesh in the way of Jesus Christ. At the heart of this is our acknowledgment and our response to the divine initiative. The life of worship is drawn into the divine goodness.' ${ }^{31}$

One way to round out this review of the conceptual and normative interrelatedness of liturgy and ethics is to note how, in revisiting the question in the 1990s, Saliers argues that Christian liturgy is 'not merely cultus,' while Christian moral norms and social-ethical practices are 'never simply or "purely" ethical'. ${ }^{32}$ Those assertions align with my

28 'The fountainhead for many of us working on relations between Christian liturgy and theology remains Alexander Schmemann .... Saliers, Worship as Theology, 13. Major liturgical theologians across a range of ecclesial affiliations have built so strongly on the Orthodox Schmemann's work that some characterize them as together comprising a particular "school" of liturgical theology. For recent engagement of his work, see We Give Our Thanks unto Thee: Essays in Memory of Alexander Schmemann, ed. Porter C. Taylor (Eugene, OR: Pickwick Publications, 2019).

29 See for examples, Alexander Schmemann, For the Life of the World: Sacraments and Orthodoxy, rev. ed. (Crestwood: St. Vladimir's Seminary Press, 1973), 124-126; and The Eucharist: Sacrament of the Kingdom, trans. Paul Kachur (Crestwood, NY: St. Vladimir's Seminary Press, 1987), 9-10. In similar fashion, German Lutheran theological ethicist Bernd Wannenwetsch made a critical analysis of the Political Night Prayer initiative in 1968 Cologne. See Political Worship: Ethics for Christian Citizens, trans. Margaret Kohl (Oxford: University Press, 2004), 31.

31 Ibid., 189.

32 Ibid., 189, 172. See also, Saliers, 'Liturgy and Ethics,' 174. 
own argument, above, for the entire Christian life as worship of God, a participation in God's biblically revealed, inspired desires for the world. The explicit, graced encounter with God in sacramental-liturgical worship constitutes its irreducible necessity for the church and its members to carry out their life-mission in and for the world. Similarly, Catholic theologians David Power and Michael Downey's proposal of the 'Christian ethic' as a way of life grounded in trinitarian faith comes through 'a doxological theology steeped in and shaped by the worship of the Christian people. ${ }^{33}$

A Christian moral theology based on virtues and character-formation depends upon the grace-dimension of liturgy, the utterly gratuitous gift of God's favor, God's loving care and mercy, experienced in moments of genuine revelation through specific symbols, words, gestures, and personages that (re)orient how believers venture into life's challenges with and for others. Encounter or accompaniment with others, both in liturgy and wider life, may be either exciting, inviting, and consoling or threatening, off-putting, and even scary; and this is so whether the Other be a fellow creature - most often but not only fellow human(s) - or God, whether apophatically or in the person of Christ Jesus. ${ }^{34}$ Openness to divine epiphany through participation in the full range of modalities ${ }^{35}$ of liturgical prayer (word, symbols, actions) shapes and reshapes over the time of life, in its continuities and disruptions, the affections and virtues - gratitude, truthfulness, compassion, solidarity - out of which believers discern their ethical commitments and choices. ${ }^{36}$

Still, we must not overstate the continuity between the affections and virtues fostered through participation in sacramental worship and their concretely being lived out in an ethics of character, as if the two are smoothly realized in human discernment and action, individual and social. Here the practical relationship between liturgy and ethics comes into play. Saliers describes this in terms of the "gap" between

33 Power and Downey, Living the Justice of the Triune God, 130. At the outset of their text, the authors make explicit that by worship they mean 'liturgy [as] the source and summit of our participation in the Divine Communion.' Ibid., xii.

34 See Ibid., 116. See also, Bordeyne, 'The Ethical Horizon of Liturgy', 131; French version, 177-178.

35 See Saliers, 'Liturgy and Ethics,' 175; and Worship as Theology, 173.

36 On liturgy as formation in discernment, see Bordeyne, 'The Ethical Horizon of Liturgy, 123-124; French version, 169-170. 
what is being liturgically enacted and the actual ways Christians live. ${ }^{37}$ This reality, nonetheless, discloses a further intrinsic characteristic in the tradition. Recognition of the practical gap, itself, is one of the graces of sanctification - that is, part of the formation of character - participation in the liturgy may effect:

The moral struggles and the awareness of ethical dispute and conflict are, if we have ears to hear and eyes to discern, found in the readings, the Psalms, and in the broken symbol at the heart of the Eucharist. Furthermore, if preaching is honest and deeply honed in the Scripture and contemporary human experience, the tensions in attempting to live out our religious ethics are made clear and taken up into the sacramental character of prayer. Ultimately this is a liberating feature of authentic liturgy: our moral anguish and our inabilities to live in accordance with the demands of the gospel are named and placed in an eschatological hope. ${ }^{38}$

In his initial essay, Saliers described the gap as a 'dialectic' built right into the traditions of liturgical prayer. ${ }^{39}$ His fuller elaboration, as quoted here from his book-length work a dozen years later, is consistent with this notion of a dialectical tension that can and, indeed, should arise in the doing of liturgy itself, bearing the potential for both spiritual and ethical conversion in the participants. Precisely on this dialectical tension between liturgy and ethics the very authenticity of sacramental worship depends - a claim, I would note, that harkens back to the primordial normative teaching in Paul's First Letter to the Corinthians. The liturgy only exists in the practice of actual communities of faith, thereby making the normative - intrinsic and conceptual - relationship between liturgy and ethics contingent on whether the assembled 'have ears to hear and eyes to discern'.

Thus, once the academic theologian has positively asserted the intrinsic relationship between liturgy and ethics within the entire Christian life as worship of God and negatively ruled out manipulating liturgy for utilitarian ends so that the nature, function, and elements of liturgy can exercise their proper character-forming potential for its participants, then 'the complexity of other relationships between liturgy

\footnotetext{
Saliers, 'Liturgy and Ethics,' 179.

Saliers, Worship as Theology, 174.

39 Saliers, 'Liturgy and Ethics,' 179.
} 
and ethics ${ }^{90}$ inevitably come to the fore. Writing two decades after his original article on liturgy and ethics, Saliers addressed four 'clusters' of concerns that constructive critics of his programmatic thesis gradually raised. ${ }^{41}$ One may fairly summarize the common underlying problem to be other socially - including, in specific contexts, ecclesially - functional attitudes, policies, practices, prejudices, priorities, as well as primary narratives, symbols, and rituals, taking prerogative over and thereby compromising the character and virtue-forming capacities of Christian liturgy. In a word, individuals and groups and even the ministerial leadership at sacramental worship may be practicing the liturgy, to invoke Charles Taylor's concept, according to a 'social imaginary' at odds with the affections and virtues liturgical celebration of the paschal mystery would foster. Taylor astutely argues that people largely do not practice their lives according to abstract theories but, rather, by 'imagining' and participating in their social surroundings according to images, stories, symbols (including historical or contemporary personages), etc. ${ }^{42}$ Such philosophical conceptualization accords with Saliers's assertion of affections and virtues as the basis for how people practice their ethical lives. ${ }^{43}$

The notion of dialectic, then, pertains beyond the dynamics within liturgy itself. Indeed, academic or second-order theology can only adequately serve the primary or first-order practice of the faith in specific contexts by attending to the ongoing, mutually confirming and correcting, dialectic between communal performance of liturgy (and other spiritual or mystical practices) and moral-ethical engagement in everyday life and society. Theorizing that problematic has been the contribution of contemporary practical fundamental theologies. Since the last third of the twentieth-century political theologians in the North and liberation theologians in the South have explained Christian faith as a praxis of liturgy and ethics, mysticism and politics. ${ }^{44}$ The relation-

40 Ibid., 174. This is Saliers's disclaimer at the end of his original programmatic statement; see above.

41 See Saliers, 'Afterword: Liturgy and Ethics Revisited,' 211-218.

42 See Charles Taylor, A Secular Age (Cambridge, MA: Harvard University Press, 2007), 171-176.

43 On Eucharist fostering an "eschatological imagination," see Andrea Bieler and Luise Schottroff, The Eucharist: Bodies, Bread, and Resurrection (Minneapolis, MN: Fortress Press, 2007).

44 See Johann Baptist Metz, The Emergent Church: The Future of Christianity in a Post-Bourgeois World, trans. Peter Mann (New York: Crossroad, 1987), 63; and Metz, Faith in History and Society: Toward a Practical Fundamental Theology, trans. of 5th 
ship between these two distinct categories of practice is necessarily dialectical, that is to say, mutually impacting, in ways that inevitably entail conversion of Christian individuals and institutions, including the liturgy, ${ }^{45}$ due to the fact that, true to biblical tradition, believers ever find themselves called to a life in but not of the world.

European political theologian Johann Baptist Metz has compellingly argued that the praxis of Christian faith is redemptive to the extent that it empowers people with virtues capable of countering and correcting forces that dehumanize themselves and others personally, interpersonally, and socially, while upbuilding what enables life to flourish therein. ${ }^{46}$ Over against the dominant European (and I would add, American) social forces of globalized capitalism, consumerism, and secularism that accelerate individualism and social-ethical apathy, mystical-liturgical practices enable capacities for sorrow and joy, mourning and expectation, generosity and gratitude, friendship and loyalty, and solidarity with others in their suffering and struggles. Insofar as Metz calls these grace-inspired capacities 'messianic virtues,' an affinity with Saliers's conceptualization of the normative relationship between liturgy and ethics is readily evident. What Metz brings to Saliers's concern for the practice of liturgy to be authentic, that is, for it to reveal the gap between the faith being celebrated through word and sacrament and the failure of or resistance to live by the virtues revealed therein, is what he identifies as the fundamental evangelical virtue upon which all others depend: poverty of spirit.

For the (somewhat shorter) second half of this paper I shall pursue with Metz the virtue of poverty of spirit. If Saliers has convincingly argued for the intrinsic and conceptual relationship between liturgy and ethics, Metz's theology of the poverty of spirit would seem to be the virtue most fundamentally bonding the two and, thus, the key to narrowing the gap between how Christians practice liturgy and how

German edition by J. Matthew Ashley (New York: Herder \& Herder, 2007), 29; Gustavo Gutiérrez, A Theology of Liberation, rev. ed., trans. Candad Inda and Matthew J. O'Connell (Maryknoll: Orbis Books, 1988), 143-156; Edward Schillebeeckx, Christ: The Christian Experience in the Modern World, trans. John Bowden, The Collected Works of Edward Schillebeeckx, vol. 7, ed. Ted Schoof and Carl Sterkens (London: Bloomsbury T \& T Clark, 2014 [1980]), 40-47 [55-61]; and Schillebeeckx, Church: The Human Story of God, trans. John Bowden, The Collected Works of Edward Schillebeeckx, vol. 10, (London: Bloomsbury T\&T Clark, 2014 [1990]), 14, 30-33 [14-15, 31-33].

45 See Bruce T. Morrill, Anamnesis as Dangerous Memory: Political and Liturgical Theology in Dialogue (Collegeville, MN: Liturgical Press, 2000), 54-60, 128-131.

46 See Metz, The Emergent Church, 4-8. 
they live ethically. As an evangelical or messianic virtue, poverty of spirit is a participation in divine grace. The human means for all such divine participation is symbolism which, to follow the seminal work of Paul Ricoeur, encompasses elements and objects of the natural world, human corporeality, persons and historical events, and, perhaps most prominently for constructing meaning, word or language itself. ${ }^{47}$ In Christian tradition, poverty of spirit is one such symbol. We need only consider how readily the symbolic phrase, "Blessed are the poor in spirit," gives rise to a broad range of thoughts, invitations, quandaries, or avoidances in those who hear or speak it. In short, I am asserting that the title of a virtue such as poverty of spirit is a symbol generative of the sort of life-ethic to which it points.

In what follows, I start by considering, with the help of Gustavo Gutiérrez, the multivalent symbolism of the word poverty, so as to clarify both its necessarily negative connotations and evangelical promise. Fundamental attention to this symbol is the hallmark of liberation theologies. Metz himself recounts how much he learned from the primary, lived theology he witnessed in visiting Latin American communities, as well as from the second-order theology produced therewith. ${ }^{48}$ Then shall follow an investigation of Metz's rich theology, biblical with a practical intent, of poverty of spirit. Finally, I shall take up the practical potential by relating the symbol, and its referent virtue, to the celebration of liturgy today.

\section{Poverty of Spirit: An Invigorating Symbol for Christian Life and Liturgy}

One of the principles of Latin American liberation theology, from which the Northern church can benefit, is its expectation that the biblical word of God promises life-changing power when read through the lens of suffering humanity who, after all, are the fundamental object of God's love throughout both testaments. ${ }^{49}$ This hermeneutical lens radi-

${ }_{47}$ See Paul Ricoeur, The Symbolism of Evil, trans. Emerson Buchanan (Boston: Beacon Press, 1967), 10-16; and Interpretation Theory: Discourse and the Surplus of Meaning (Fort Worth: Texas Christian University Press, 1976), 53-63.

48 See Metz, The Emergent Church, 82-94; and Morrill, Anamnesis as Dangerous Memory, 46, 55-57.

49 See, for example, Gustavo Gutiérrez, The Power of the Poor in History, trans. Robert R. Barr (Maryknoll: Orbis Books, 1983), 94-96. 
calizes Christian faith by confirming the urgency of human need in real contexts, such that any symbol in the tradition can only be effectively engaged in real (versus some imagined 'spiritual') life by attending first to its situation in nature and history. ${ }^{50}$ To develop an effective theology of poverty of spirit, then, requires attention to the historical realities of human poverty, such that the spiritual power for redemption and liberation in the paradoxical poverty Christ announces in the Beatitudes (Mt 5:1-12; Lk 6:20-26) may become clearer, if not compelling.

Gustavo Gutiérrez, in his landmark work, A Theology of Liberation, came to distinguish three types of poverty evident in contemporary Christian faith practiced in the material, social conditions of Latin America. ${ }^{51}$ At the base is privation, material poverty, which widely takes physical, cultural, and psycho-social forms, reducing those in its throes to non-persons, subhuman and insignificant. While subjected to what can only be judged scandalous living conditions, Gutiérrez notes, the poor nonetheless have great gifts, virtues, to share among themselves and toward those not oppressed, even the oppressors. ${ }^{52}$ The virtues practiced by the poor are characterized by finding one's balance not just (or even) in one's self but in relation to others, which so often is a matter of profound conversion. But such giftedness among the poor is born of another type of poverty, quite different in nature. Spiritual poverty, Gutiérrez explains, is a life approached in complete dependence upon the love of God, life as a child of God, totally open to God, available to hearing the word of God, with a desire that God be one's sole sustenance. This is not passive acceptance of one's material, socially inflicted conditions but, rather, an embracing of reality empowered by the Spirit of God. ${ }^{53}$

Finally, Gutiérrez delineates a third type of poverty, the evangelical poverty practiced in solidarity with those who suffer privation, a lived commitment and protest against scandalous poverty. What makes this poverty evangelical is the willingness to risk all one has

\footnotetext{
See Gutiérrez, A Theology of Liberation, 83-97.

51 The following rehearsal of Gutiérrez's three-part analysis of poverty is based on Ibid., 163-171.

52 For another example of this widely held observation-cum-testimony to the virtues of the poor, see Jon Sobrino, No Salvation Outside the Poor: Prophetic-Utopian Essays (Maryknoll: Orbis Books, 2008), 17, 52-53, 62-63.

53 Elsewhere in his writings, Gutiérrez describes the eucharistic celebrations in the poor communities of Latin America as their character-empowering share in Christ's paschal mystery. See The Power of the Poor in History, 107.
} 
and is in a Christ-like kenosis, a voluntary empowerment out of loving solidarity with the poor. This characteristic of risking all is likewise essential to Jon Sobrino's 'principle of mercy,' an attitudinal life-structure of making the other's pain one's own, such that one is moved to respond. ${ }^{54}$ When thus practiced in a 'de-centered church,' in community and against all societal odds, Christian faith becomes 'an active hope which unloosens creativity at all levels of human existence. ${ }^{55}$ Sobrino developed this concept from his context in El Salvador explicitly for the benefit of North American readers struggling to understand how opting for life in solidarity with the poor proves redemptive and liberating. In what amounts to an invitation, Sobrino describes a conversion of the educated European Christian (that is, himself) who no longer looks only to the crucifix in prayer and liturgy but also to the crucified people ${ }^{56}$ of our time. Only in that way does the truth of faith become practical or, as Gutiérrez would say, evangelical.

As leading theorist of the new political theology in Europe, Johann Baptist Metz put in fundamental-theological perspective what Sobrino autobiographically called the 'slumber' of (individualistic, pure-reason-focused) first-world, "progressive" theology. ${ }^{57}$ Metz argued that theology was being done in a strange, idealist-transcendental enclosure ignoring twentieth-century's human catastrophes, forgetting Auschwitz. The latter stands as a symbol for Europeans analogous (but only that!) to the crucified people of El Salvador. As an antidote to this bourgeois, self-absorbed Christianity, Metz proposes poverty of spirit. Whereas he produced a little monograph by that title in $1968,{ }^{58}$ one finds that he radicalized the entire notion in a 1990 essay, 'Theologie als Theodizee. ${ }^{59}$ To my thinking, insofar as Christianity is a religion of deliverance and redemption, Metz was quite right in centering the question of theology's validity, and thus, very viability, on the problem of suffering, of evil's manifestation in sinfulness both conceived

\footnotetext{
Recall the similar argument by Bordeyne and Spohn, earlier.

55 Jon Sobrino, The Principle of Mercy: Taking the Crucified People from the Cross (Maryknoll: Orbis Books, 1994), 6, 21-22.

56 See Ibid., 49-57.

57 See Ibid., 1-3.

58 Johannes Baptist Metz, Poverty of Spirit, trans. John Drury and Carole Farris (New York: Paulist Press, 1968/1998).

59 English trans., 'Theology as Theodicy,' in Johann Baptist Metz, A Passion for God: The Mystical-Political Dimension of Christianity, trans. J. Matthew Ashley (New York: Paulist Press, 1998), 54-71.
} 
as a broad human condition and recognized in particular human acts, corporate and individual.

Metz argues that theodicy, as a genuine questioning of God in light (or, perhaps, the dark) of suffering, receded from theology as Augustine turned the question away from God and back onto humanity. Metz perceives Augustine seeking to resolve the problems a centuries-persistent Marcionism was causing for orthodox faith: '... using a gnostic dualism of a creator and redeemer God, [Maricion] tried to close the open flank of the theodicy question, which accompanies the historical development of biblical discourse about God in the form of crying-out and inconsolable expectation. The early church decisively rejected this offer, ${ }^{60}$ Augustine, however, shifted the blame onto freely, badly acting humans, effectively replacing theodicy with 'anthropodicy'. Still, Metz questions, in the end whether Augustine did not draw a Marcion-like dualism back into theology with the notion of predestination of the elect and the damned. With this came a certain timeless quality to salvation, the salvation of the eternal soul, leaving time itself, that is, human history, something to be circumvented and, ultimately, escaped.

As a fundamental corrective (with practical intent), Metz proposes an 'Israelite-Biblical Paradigm' for theodicy. Christian theology should not turn to Israel only for its 'faith,' while deriving its 'spirit' from the Greeks but, rather, should embrace the Israelite spirit as well. ${ }^{61}$ Unlike Platonic anamnesis, Israel's is a historical 'remembrancing, ${ }^{, 62}$ a liturgically-grounded remembering with the God of the covenant that refuses to forget history, to erase its victims.

What is it that distinguished pre-Christian Israel, what is it that distinguished this small, culturally rather insignificant and politically humble desert folk from the glittering high cultures of its time? In my view it was a particular sort of defenselessness, of poverty, in a certain sense Israel's incapacity successfully to distance itself from the contradictions, the terrors and chasms in its life. ${ }^{63}$

60 Metz, A Passion for God, 59.

61 Ibid., 64. Here Metz takes issue with a thesis Joseph Ratzinger asserted in 'Eschatologie und Utopie,' Internationale katolische Zeitschrift Communio 6 (1977): 97-110.

${ }_{62}$ This English neologism translates the German Eingedenken, which the translator explains Metz derives from the adverb eingedenk, meaning 'in remembrance of,' as used in the church's Eucharistic Prayer. See Metz, A Passion for God, 181, n. 10. Ibid., 65. 
Against the temptation to embrace alien myths and fables - whether for historic Israel, those of Babylonian or Greco-Roman deities and humans, or for contemporary Christians, the totalizing myths of modern progress or the scientific elimination of suffering - Metz asserts: 'Poverty of spirit is the foundation of any biblical discourse on God'. ${ }^{64}$ To practice poverty of spirit is to suffer unto God (Leiden an Gott) in constant, time-limited expectation. The church thereby 'exposes itself ... shows an open flank,' united with suffering humanity, 'a pathic monotheism, with a painfully open eschatological flank'. ${ }^{65}$

With his theology of remembrancing, of anamnesis and anticipation, Metz points toward time and, thus, eschatology, as being of the essence of Christian liturgy. This requires thinking and practicing liturgy as not only, nor even primarily, incarnational but, rather paschal, grounded in the paschal mystery. ${ }^{66}$ The problem with an incarnational-sacramental approach to liturgy is that it can foster a static image of salvation as completed in past events. Liturgy and ethics become a matter of recalling all Christ suffered 'for me' such that I resolve, once again, to do better, to avoid sin and to try to imitate him and, perhaps, the saints. A graceless Pelagianism can seep into Christianity, such that sacraments become rewards to be earned rather than the empowering sources of one's identity with Christ Jesus as a child of God, a Spirit-anointed participant - here and now, mystically and ethically - in the coming reign of God.

[The biblical concept] mysterium refers to a reality that surpasses human thought and is irrevocably bound up with revelation. It is a gracious gift of God. Jesus Christ is the mystery of God into which believers are drawn for their salvation. It is present in the community in which it is proclaimed. This is a clearer concept than [the Roman military] sacramentum for expressing the salvation-historical dimension of the liturgical celebration. Mysterium thus points to both the present and the eschatological

\footnotetext{
Ibid., 66.

Ibid., 112, 127.

66 For his critique of scholastic theology in this regard, followed by his constructive, paschal-mystery approach, see Louis-Marie Chauvet, Symbol and Sacrament; A Sacramental Interpretation of Christian Existence, trans. Patrick Madigan and Madeleine Beaumont (Collegeville, MN: Liturgical Press, 1995), 449-489.
} 
dimensions of Christian liturgy as well as to the faith that in the celebration of the liturgy one participates in the divine saving action in Christ. ${ }^{67}$

Celebrated from that latter perspective, sacramental liturgy reveals God's cosmic and historical salvation of the world as an unfinished project in which we can genuinely, actively participate because it is being revealed as ongoing, reaching from and into a future whose promise can be hoped on the basis of God's definitive past deeds, climactically in Jesus. ${ }^{68}$

To perceive how this celebration of mystery in liturgy can be formative of the virtue of poverty of spirit, I conclude by considering one symbol within the service of Good Friday, the midpoint in what the church considers the most sacred, three-day liturgy of the entire church year. Focused on the death of Christ Jesus, the service enacts in mystery what faith discerns to be not the nadir but the apotheosis of his poverty of spirit, making it the very source, initiated but ongoing, of believer's sharing in that spirit. The dynamic of divine glory and human salvation (justification and sanctification), which is to say, the paschal mystery, is so intensely experienced - revealed and shared - in the proclamation of and communal response to the word of God in the Good Friday service as to make it paradigmatic - theologically and practically - of the liturgy's capacities for deepening in the assembled faithful a mystical participation in Christ Jesus' poverty of spirit, through which all their affections and virtues may practically thrive.

\section{The Open Flank: A Biblical-Liturgical Expansion of Metz's Symbol}

Metz's symbolism of Christianity's poverty of spirit as an open flank he seems to have constructed from military imagery of exposure and vulnerability to attack. But as a liturgical theologian I find the symbol elicits a more theologically profound image steeped in the paschal

${ }_{67}$ Albert Gerhards and Benedikt Kranemann, Introduction to the Study of Liturgy, trans. Linda M. Maloney (Collegeville: Liturgical Press, 2017), 196.

68 'With liturgy being the source and summit of our participation in the Divine Communion, indeed a share in God's own justice, the moral and spiritual life are moored in both memory and in hope.' Power and Downey, Living the Justice of the Triune God, xii. For doctrinal presentation of the eschatological dimensions of the liturgy, see Constitution on the Sacred Liturgy, nos. 8, 14, 48. 
mystery: the wounded, open side of the dead, crucified Jesus. While depicted in crucifixes looming over the altar of Eucharistic sacrifice, the image likewise features in Good Friday's liturgy of the word, wherein proclamation of the pierced Suffering Servant (Is 53:5) points toward the soldier lancing open the side of Jesus' crucified body.

Among multiple unique features in the passion account of John's gospel is a detail found at 19:34: A solider thrusts a lance into the side of Jesus' body to determine if he is dead. Blood and water immediately flow from that completely vulnerable, open flank. Discharge of water and blood is birthing imagery. Jesus' death gives birth to life, is the source of new life for believers and, thus, is the birth of the church. The moment of Jesus' most abject poverty, having surrendered even his very spirit (19:30), proves to be the hour of his glory, ${ }^{69}$ the culmination of his entire life as given for the life of his believers and, indeed, for the life of the world. Biblical scholar Barbara Reid explains how John theologically constructs this revelation:

The language of birthing is prominent throughout the whole gospel, culminating with this image of Jesus' death as a birth to new life. The theme is first sounded in the prologue which speaks about those who believe as being born of God (1:12-13). Then, when dialoguing with Nicodemus, Jesus talks about the necessity of being born again/from above (3:3). At the Feast of Dedication (7:38) he speaks about 'rivers of living water' that flow from his own and the believer's heart (koilia, which is literally, "womb"), foreshadowing John 19:34. At his final meal with his disciples, Jesus likens the pain of his passion to the labor pangs of a woman giving birth (16:21-22). All these texts point forward to John 19:34, where the birth to new life that was begun with Jesus' earthly mission comes to completion in his death. ${ }^{70}$

The cross begins Jesus' ascent to the Father and, with that, his saving Lordship, manifesting his power to give eternal life to all who believe, to all who see 'the only true God' (17:3) in this Jesus who finishes the earthly work the Father sent him to do (see 17:4).

69 See Schillebeeckx, Christ, 398-404 [409-415].

70 Barbara E. Reid, 'From Sacrifice to Self-Surrender to Love,' Liturgical Ministry 18 (Spring 2009): 86. Reid notes that such early Christian bishops as Ambrose of Milan and medieval mystics as Julian of Norwich drew on the Johannine birthing imagery to describe Christ as the mother giving birth to believers. 
The liturgical proclamation and sacramental sharing in that saving revelation on Good Friday, however, is not merely the recounting of a completed, past event, one eliciting grief or, to tragic effects in history, even outrage at what was done to Jesus. ${ }^{71}$ Good Friday's liturgy of the word, rather, concludes with the assembly of the baptized responding in a series of ten prayerful intercessions reaching out from the center, for the church's leadership and all its membership, to all who believe in God (starting with the Jewish people, first to receive the covenant), to nonbelievers, and finally to all suffering forms of material poverty. In so doing the members of the assembly identify themselves with Jesus's earthly mission as now their mission. If the passion constitutes the hour of Jesus's glory, the community, in turn, glorifies God by living in the spirit Jesus gives over at his death, with the water and blood flowing from his pierced side signifying baptism and Eucharist as the life-giving sacraments whereby the Spirit comes powerfully to abide in them. ${ }^{72}$

The great intercessions of Good Friday are poised between the proclamation and reception of the word of God and the sacramental act of venerating the cross. The community does not move directly from gospel to a personal act of liturgical piety; rather, the assembly responds to God's word by giving concrete historical expression to the universal saving will of God and, in so praying, implicating their baptismal identification with that mission in Christ. This is but one way the Good Friday service, at the center of the Easter Triduum, serves as a paradigmatic experience of the weekly Lord's Day liturgy's capacities for drawing participants into the paschal mystery, thereby gracing them with the messianic virtues symbolically expressed in the proclaimed word, shared sacrament, and the prayers arising from the assembly.

Commentators, Protestant and Catholic, agree on early Christianity's association of John 19:34 with the ecclesial sacraments, noting also the passage's relation to the instruction John gives in the First Epistle. ${ }^{75}$ The Spirit, the water, and blood all 'testify' (1 John 5:7) to the

71 Medieval liturgical celebrations of Good Friday in central and eastern Europe, with preaching and prayers following from the Johannine passion, could result in attacks on Jewish storefronts, synagogues, and persons, even rabbis.

72 See Rudolph Schnackenburg, The Gospel according to St. John, vol. 1, trans. Kevin Smyth (New York: Crossroad, 1982), 396, 161.

73 See D. Moody Smith, 'John,' in Harper's Bible Commentary, ed. James L. Mays (San Francisco: Harper \& Row, 1988), 1074. Even Rudolph Bultmann recognized the water 
Christ Jesus from whose flesh they flow, making them the source of the 'presence of the absent one'. ${ }^{74}$ That presence is known mystically in word and sacrament, but these only for the purpose of empowering the members of Christ's mystical body (the church) to know him in their social-ethical lives, wherein the painful eschatological tension of grace and sin takes real form in a faith sustained by a fierce, abiding love lived out in genuine, vulnerable hope. Such comprises a dense summation of the truth proclaimed in the second readings for the seven Sundays of Easter, in which 1 John alternates with 1 Peter and Revelation through the three-year lectionary cycle. Those books, in offering realistic appraisals of not only the consolations but also the challenges of living paschal faith both within the ecclesial community and amidst a troubled if not oppressive, world, reveal faith in the Risen Crucified One as an ongoing praxis of mysticism and ethics. Embodying joy amidst both concord and conflict, participants realize what Schillebeeckx described as fragmentary moments of the inbreaking of God's reign. ${ }^{75}$ Fragments, only, are what we have until the fullness of Christ is revealed. The 'already' of biblical Easter faith certainly resides in proclamation of Christ resurrected, but it only lives and breathes in the sacramental body of Christ, the church in its members, for whom their sacramental worship serves as source and summit for living the virtues in concrete behavior. That is what the ancient tradition of mystagogy was all about. ${ }^{76}$ And, so, liturgical restoration in the church may well prove a matter of such mystical-ethical preaching, from and to poverty of spirit, being realized in the global contexts of our day.

\section{Conclusion}

Article 7 of Sacrosanctum Concilium, having delineated the liturgical presence of the Risen Crucified One in the assembly, presiding minister, proclaimed word, and shared sacrament, proceeds to explain the import of this divine-human presence: 'Christ always truly associates

and the blood as symbols of the two sacraments, while nonetheless denying the verse's authenticity to the Fourth Gospel.

74 Francis J. Moloney, 'Johannine Theology,' in The New Jerome Biblical Commentary, ed. Raymond Brown, and others (Englewood Cliffs: Prentice Hall, 1990), 1426.

75 See Schillebeeckx, Church, 5-6 [5-6]; and Christ, 829-834 [834-839].

76 See Goffredo Boselli, The Spiritual Meaning of the Liturgy: School of Prayer, Source of Life, trans. Barry Hudock (Liturgical Press, 2014), 14. 
the Church with himself in this great work wherein God is perfectly glorified and the recipients made holy. The Church is the Lord's beloved Bride who calls to him and through him offers worship to the eternal Father'. Unless taught and practiced with relentless study and proclamation of the biblical God of Jesus, religious rhetoric along the lines of glory and holiness can leave people convinced of sacramental worship's irrelevance to 'real life,' to their ethical quandaries and moral concerns. But God in scripture glories in the salvation, redemption, and deliverance of a humanity whose sanctity entails loving that God wholeheartedly by sharing in that divine, active love among selves and 'neighbor'. Such practical love is borne of an evangelical poverty of spirit that mourns, comforts, strives for justice, shows mercy, and works for peace. And so, Metz: 'It is no accident that "poverty of spirit" is the first of the beatitudes ... only through it does God draw near to us' $^{97}$ Demonstrating and witnessing to such virtue constitutes the desire to share liturgically in the paschal mystery. The sacramental assembly indeed 'calls to her Lord,' but in the expectant plea of martyrs, witnesses of faith, hope, and love wedded to Christ in the Spirit. Their response to Christ's assurance, 'Yes, I am coming soon,' is an urgent, 'Amen! Come, Lord Jesus'. Thus concludes the reading from Revelation $(22: 12-14,16-17,20)$ on the Seventh Sunday of Easter. The asking comes from a mystical-ethical poverty of spirit. The sacramental-liturgical empowerment comes in the asking.

Edward A. Malloy Chair in Roman Catholic Studies Vanderbilt University Divinity School

Nashville, Tennessee, USA E-mail: bruce.morrill@vanderbilt.edu

${ }_{77}$ Metz, Poverty of Spirit, 21. 